\title{
A Documentation on Dioscorea spp. (A neglected Wild tuber) with Special Reference to its Domestication and Seasonal Food Security to the Indigenous Forest Dwellers in Tripura, India
}

\section{Chiranjit Paul*, Amal Debnath, Bimal Debnath}

Plant Diversity and Forest Biotechnology Laboratory, Department of Forestry and Biodiversity, Tripura University, Suryamaninagar-799022, Agartala, Tripura, India

Study Area: Tripur, India

Coordinates: $22^{\circ} 56^{\prime \prime}$ to $24^{\circ} 32^{\prime \prime} \mathrm{N}$ and $90^{\circ} 09^{\prime \prime}$ to $92^{\circ} 30^{\prime \prime} \mathrm{E}$

Keywords: Food value, Regeneration status, Traditional food

\section{Abstract}

Wild Dioscorea (Yams) are such type of tuber crop that may be considered as a potential alternative source offering the food security to the indigenous forest dwellers of Tripura, India. This wild tuber crop is one of the major food sources among different tribal communities of Tripura. Till date, total ten Dioscorea species have been reported from the state. Among them, eight species are directly exploiting from wild, whereas only two species are found in the home garden of tribal as well as non-tribal dwellers in the state. Six species such as D. alata, D. glabra D. hamiltonii, D. oppositifolia, D. pubera and D. esculanta var. spinosa are consumed as a vegetable by the majority of the communities. The people of all communities keep away themselves from the tuber of $D$. hispida and $D$. bulbifera var. bulbifera as vegetable due to its bitter and toxic nature. The most preferred and valuable edibles species are $D$. alata and D. hamiltonii. Dioscorea species which also play an important role in their daily health care system. Dioscorea tuber contains noticeable nutrition content, easy propagation methods, attractive therapeutic properties, and long-term storage capacity.

deficient policy frameworks. Among the ethnic forest food plants, the tuberous species play a significant role in supplementing the food requirements of indigenous people in isolated areas through conserved foodstuffs during the time of food shortage. Sometimes the nutritional value of traditional tubers or root vegetables are found to be considerably higher than several known common cultivated ones (Schoeninger et al., 2001; Huang et al., 2007). Most of the wild tuberous vegetables have the potential for increased income generation and making varieties of quality food items. In spite of having easy propagation methods, storage and preservation ability they are unable to compete with cultivated or exotic vegetables due to lack of awareness and proper harvesting. Dioscorea Lin. is a genus having over 600 species (Ayensu, 1972) of tuberous herbaceous angiospermic climbers, climbing up to 20 meters by supports. The genus belongs to Dioscoreaceae of Dioscoreales. Species of Dioscorea are native throughout the tropical, especially in tropical America, subtropical and warm temperate regions of the world, with only a few species extending into the temperate minute research devotion, proper commercialization, and

*Corresponding Author: Chiranjit.paul869@gmail.com 
regions (Caddick et al., 2002; Seikh et al., 2009). The genus Dioscorea has been the most important food source for tribal people particularly in several parts of West Africa since prehistoric times because its tubers are rich in necessary dietary nutrients (Coursey, 1967; Hladik \& Dounias, 1993) and medicinal uses in different part of the world as well as from India (Choudhary et al., 2008; Dutta, 2015; Ghosh, 2014). The impoverished indigenous people of Tripura mostly be relying on forest plant products for their daily livelihood. The traditional knowledge of using plants for their undulating survival is continuing from generation to generation. Each group of tribal people offers unique methods of practice and preservation that were based on their traditional knowledge. At present due to the rapid increase of rubber cultivation, natural habitat in Tripura have been fastly decreasing, the indigenous peoples are losing the sources of wild foods and folk medicines in this remote state. There is no existing literature on Dioscorea as an alternative food resource and their respective role in primary health care from the state. Therefore, the present study was designed to document the status of Dioscorea secies available in the state and to highlight the dependence of study communities on this genus for their seasonal food security and primary health care.

\section{Methodology:}

Study area: Tripura, the East Himalayan foothill state of Northeast India, cover $10,491 \mathrm{~km} 2$ area, is the homeland of 19 primitive groups which comprises $33 \%$ of the state population $(36,710,321)$. Majority of this population is mainly residing in the different forest tracks and margin which are naturally isolated from the urban society, where $60 \%$ of the area is covered by forest. The temperature of this region ranges from $7^{\circ}$ to $37^{\circ} \mathrm{C}$ with $220 \mathrm{~cm}$ of average rainfall.

Ethnic communities: a total 13 ethnic communities were selected for this study, viz., Tripuri, Jamatia, Reang, Chakma, Bhil, Halam, Kuki, Munda, Darlong, Mog, Noatia, Debbarma, and Murasing. All these tribal groups of Tripura have their own festivals, rituals, and customs. Living in the various forest patches and remote hilly zones of the State for a long time, specific and unique lifestyle is developed within each group of the tribal community in the State..

Exploration: the survey was conducted in the different district of Tripura during July 2014 to January 2016. Numbers of visits were made to the targetted communities to build up the understanding with the local people and members of the study communities. The information about Dioscorea was collected by a discussion with the same communities of Tripura for gathering information about all the species of Dioscorea used as a food and vegetable as well as medicines. Different markets were also surveyed to gather information on the market potential of the wild tubers, including their availability and buyer preferences. Analysis of data was made with the help of group discussions among different age classes of study community that include both the genders of the society. Repeated queries were made for confirmation and data gathered of each plant was cross-checked for further verification. Plants were collected in its flowering and fruiting stage from their natural habitat. Herbarium sheets were prepared (Jain \& Rao, 1997) and deposited in The Department of Forestry and Biodiversity. Each plant species was identified using flora of Tripura (Deb, 1983) and flora of Assam (Kanjilal et al., 1939)..

\section{Results and Discussion:}

Our study documented ten Dioscorea species from the forest floors as well as from the home gardens of tribal and non-tribal communities of Tripura. These ten Dioscorea species are D. alata L., D. bulbifera var. bulbifera L., D. glabra Roxburgh, D.hamiltonii Hook. f., D.pentaphylla L. and D.pubera Blume., D.hispida Dennstedt, and Dioscorea oppositifolia L., Dioscorea wallichii Hook.f and Dioscorea esculenta var. spinosa (Roxb. ex Wall.) R. Knuth. Out of these ten Dioscorea species, only two species; D.alata, and D.esculanta var. spinosa were commonly noticed in home gardens, as a cultivated species in tribal as well as non-tribal dwellers in the state and other species were found in wild habitat. Tubers, Bulbils and shoot tips of Dioscorea species are used as a vegetable by the indigenous people of Tripura. During the present survey it was also found that out of ten Dioscorea species; tubers of six species; D. alata, D. pubera, D.glabra, D.hamiltonii, D.esculanta var. spinosa and D.oppositifolia are consumed as vegetable by the majority of the communities. Only few communities used tuber of D. wallichii and D.pentaphylla as vegetable due to its hardness. Young tender shoots of D.wallichii are also found to be used as vegetable. However all the communities avoid tuber of D.hispida and D.bulbifera var. bulbifera as a vegetable due to its bitter and toxic nature. The most preferred and valuable edibles species are D.alata, $D$. hamiltonii which had the highest market value (6o-10o Rs./Kg) in Tripura then other edible species.

\begin{tabular}{llllllll}
\multicolumn{8}{c}{ Table-1: Comparison of nutrient content between Dioscorea } \\
tuber and other crops (Kumar et al., 2017)
\end{tabular}

${ }^{*}$ Component/1oogm

Our survey also revealed that most of the Dioscorea species regenerate through bulbil, seed, and tuber but some species regenerate through the tuber and seeds because they did not produce bulbil, so it easily propagates. Dioscorea tuber possesses a rich source of dietary nutrients 


\section{AMBIENT APPRAISAL}

and remains their ranks fourth as a most important tuber crop in the world after potato, cassava and sweet potato ( Lev \& Shriver, 1998; Kumar et al., 2017). Sometime Dioscorea tuber contains higher nutrient content than the other known vegetables. According to Arnau et al. (2010) Dioscorea have a superior tuber crop as important medico food by about 300 million people throughout the world because it also possesses highly medicinal properties due to the presence of diverse secondary metabolites.

Table-2: List of traded species with prevailing value

\begin{tabular}{llllll}
\hline \multirow{2}{*}{$\begin{array}{l}\text { Dioscorea } \\
\text { Species }\end{array}$} & \multicolumn{5}{c}{$\begin{array}{l}\text { Mame of Market/Bazar [Rate/kg (in rupees)] } \\
\text { Lake }\end{array}$} \\
\hline chowmoni & Natun Pacharthal Karbok \\
\hline alata & $20-30$ & $40-50$ & $30-35$ & $35-45$ & $30-40$ \\
D.hamiltonii & $50-60$ & $60-70$ & $40-50$ & $40-50$ & $40-50$ \\
D. glabra & $30-40$ & $35-40$ & $35-40$ & $30-40$ & $30-40$ \\
D. oppositifolia & $25-30$ & $30-40$ & $30-35$ & $25-35$ & $20-30$ \\
D.pubera & $20-25$ & $50-60$ & $30-35$ & $20-30$ & $25-35$ \\
D. wallichii & $10-15$ & $20-25$ & $15-20$ & $15-20$ & $10-20$ \\
\hline
\end{tabular}

Dioscorea species play a significant role in the daily health care system of the residents tribal. Indigenous peoples of Tripura used Dioscorea species for the curing of various ailments like tuber of $D$. bulbifera var. bulbifera and D. hispida used for skin infection, D. hamiltonii tuber paste used stomach disorder and Leaf and tuber of D.oppositifolia used for snake bite.

Conclusively, the domestication of these wild Dioscorea sp. will not only improve the economic condition of the local people but also help in the conservation of biodiversity. Proper care should be taken to conserve these wild germplasm. From this study, it is suggested that domestication of these wild genetic resources may lead to the discovery of alternative food resources.

\section{Acknowledgements:}

The authors are highly thankful to the local communities of the villages for sharing their valuable information with us. The first author is also thankful to the UGC non-net fellowship for providing financial support which helped to carry out this work.

\section{References:}

Ayensu, E.S.(1972): Anatomy of the monocotyledons, Vol. VI. Dioscoreales. Pub. by: Oxford Press, Oxford. 182 p.

Arnau, G., Abraham, K., Sheela, M.N., Chair, H., Sartie, A. \& Asiedu, R. (2010): Yams, pp 127-148. in Bradshaw, J.E. (Ed.) Root and Tuber Crops, Handbook of Plant Breeding, Pub. by: Springer Science Business Media, LLC, Singapore.

Balemie, K. \& Kebebew, F. (2006): Ethnobotanical study of wild edible plants in Derashe and Kucha Districts, South Ethiopia. J. Ethnobiol Ethnomed., 2(53):1-9.

Caddick, L.R., Rudall, P.J., Wilkin, P., Hedderson, T.A.J. \& Chase, M.W. (2002): Phylogenetics of Dioscoreales based on combined analyses of morphological and molecular data. Bot. J. Linn. Soc., 138(2):123-144.

Choudhary, K., Singh, M. \& Pillai U.(2008): Ethnobotanical survey of Rajasthan-an update. Am-Eu.J. Bot., 1(2):38-45.

Coursey, D.G.(1967): Yam: An Account of the Nature, Origins,
Ambient Science, 2018: Vol. 05(2); 51-53 DOI:10.21276/ambi.2018.05.2.aa02

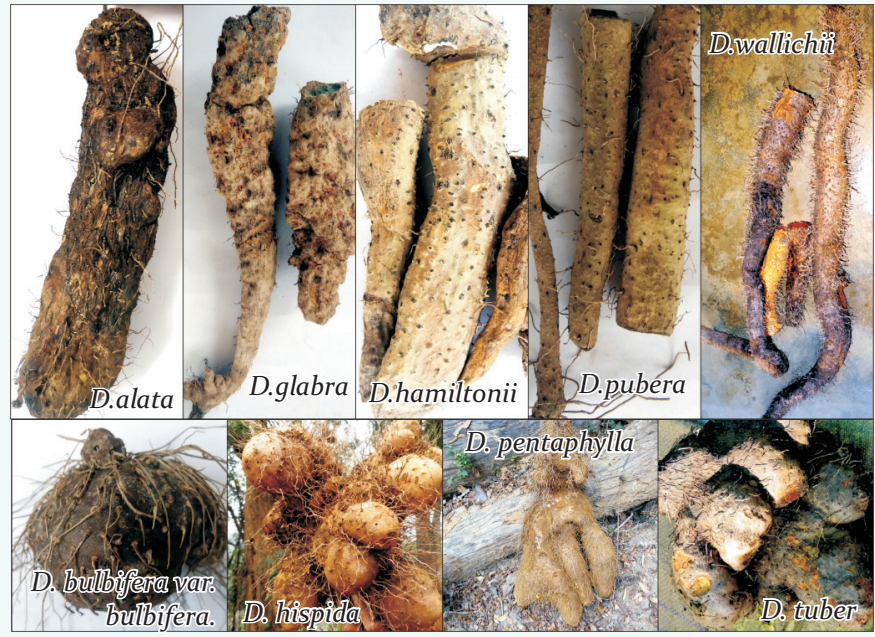

Plate-1: Some of the common Dioscorea sps. collected during the survey

Cultivation and Utilization of the Useful Member of the Dioscoreaceae. Pub. by: London: Longmans, Green \& Co. Ltd. 224p.

Deb, D.B. (1983): The Flora of Tripura state, Vol. 2 Pub. by: Today \& Tomorrows' Printers and Publishers. New Delhi, India.

Dutta, B.(2015): Food and medicinal values of certain species of Dioscorea with special reference to Assam. L. Pharmacogn. Phytochem., 3(4):15-18.

FAO (Food \& Agriculture Organization of the United Nations). (2004): The state of food insecurity in the world (monitoring the progress towards the world food summit and millennium development goals. Ann.Rep.), Rome. 43p.

Ghosh, A.(2014): The genus Dioscorea L. In Andaman and Nicobar Islands, India. Indian J Plant Sci., 3(3):7-14.

Hladik, A. \& Dounias, E.(1993): Wild yams of the African forest as potential food resources, in Hladik C.M. et al. (eds.)Tropical Forests, People and Food: Biocultural Interactions and Applications to Development. Pub. by: Paris and the Parthenon Publishing Group, London.163-176.

Huang, C.C., Chen, W.C \& Wang, C.C.R. (2007): Comparison of Taiwan paddy and upland cultivated taro (Colocasia esculenta L.) cultivars for nutritive values. Food Chem, 102:250-256

Jain, S.K. \& Rao, R.R.(1977): A Handbook of Field and Herbarium Methods. Pub. by: Today and tomorrow's Printers and Publishers, New Delhi. 157 p.

Kanjilal, U.N., Kanjilal, P.C., Das, A. \& De, R.N. (1939): Flora of Assam, Dehradun, Vol. III. Caprifoliaceae to Plataginaceae. Pub. by: Government of Assam.

Kumar, S., Das, G., Shin, H.S. \& Patra, J.K.(2017): Dioscorea spp. (A Wild Edible Tuber): A Study on Its Ethnopharmacological Potential and Traditional Use by the Local People of Similipal Biosphere Reserve, India.Front Pharmacol., 8:52.

Seikh, N., Kumar, Y., Misra, A.K. \& Pinokiyo, A. (2009): Status documentation of Dioscorea L. (Dioscoreaceae) in Meghalaya: an approach towards food security. Pleione, 3(1):74-82.

Schoeninger, M.J., Bunn, H.T., Murray, S.S. \& Marlett, J.A.(2001): Composition of tubers used by Hadza foragers of Tanzania. $L$. Food Compos. Anal., 14:15-25. 